I N S T I T U T O

$\mathrm{DE}$

M E D I C I N A

T R O P I C A L

DE

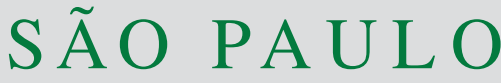

JOURNAL OF THE SÃO PAULO INSTITUTE OF TROPICAL MEDICINE

1Universidade Federal de Pernambuco,

Setor de Virologia, Laboratório de Imunopatologia Keizo Asami, Recife, Pernambuco, Brazil

${ }^{2}$ Fundação Oswaldo Cruz, Instituto Aggeu Magalhães, Departamento de Virologia e Terapia Experimental, Recife, Pernambuco, Brazil

${ }^{3}$ Instituto Federal de Educação, Ciência e Tecnologia do Sertão Pernambucano, Floresta, Pernambuco, Brazil

Correspondence to: José Valter Joaquim Silva Júnior

Fundação Oswaldo Cruz, Instituto Aggeu Magalhães, Departamento de Virologia e Terapia Experimental, Cidade Universitária, CEP 50670-420, Recife, PE, Brazil

E-mail: josevalterjsilvajr@gmail.com

Received: 15 July 2018

Accepted: 17 July 2018
http://dx.doi.org/10.1590/S1678-9946201860043

\title{
Dengue in Brazil in 2017: what happened?
}

\section{Dear Editor}

Brazil is a dengue-endemic country and over the years has been facing several outbreaks caused by different serotypes of the virus. More recently, between 2015 and 2016, the country reported an annual average of 1,586,155 probable cases ${ }^{1,2}$. However, in 2017, two or four years after the probable introduction of Zika virus $(\mathrm{ZIKV})^{3,4}$, Brazil experienced a decrease in dengue fever to 252,054 cases, besides a reduction in the number of severe dengue and deaths ${ }^{2}$.

In 2017, the number of Zika cases also declined in Brazil in comparison to the previous year, about $92 \%$ reduction ${ }^{2}$. The decrease in Zika cases influenced by anti-ZIKV herd immunity has already been previously discussed ${ }^{5,6}$. However, regarding dengue disease, the causes of this decline are still not fully understood. Indeed, as shown below, the current data on herd immunity, cross-reactions between Dengue virus (DENV) and ZIKV, mosquito ecology, vector control measures and environmental factors are not sufficient to explain the dengue scenario in 2017.

First, the anti-dengue herd immunity does not seem to explain the decline in dengue cases in 2017. In Brazil, between 2009 and 2016, DENV-1 was the most prevalent serotype ${ }^{7}$. In the year 2015 , for instance, the prevalence of DENV-1, DENV-2, DENV-3 and DENV-4 was 94.1, 0.7, 0.4 and 4.8\%, respectively ${ }^{8}$. In the same way, in 2016 (up to epidemiological week 4), prevalences were 97.24, 0.69, 0.69 and $1.38 \%$ to DENV-1, DENV-2, DENV-3 and DENV-4, respectively ${ }^{8}$. In 2017 , however, serotype 2 was the most prevalent $(54.3 \%)^{7}$. This very low prevalence of DENV-2 in the years 2015 and 2016 reduces the possibility that dengue cases have fallen in 2017 due to the anti-DENV-2 herd immunity.

In another perspective, the studies on cross-reactivity between DENV and ZIKV also do not explain the fall in dengue cases in 2017. Regarding anti-ZIKV immunity in relation to DENV infections, to our knowledge, there are only two reports on the in vivo modulation of anti-ZIKV antibodies with respect to DENV infection: Stettler et al. ${ }^{9}$ and George et al..$^{10}$ demonstrated the increase of DENV-2 infection by anti-ZIKV antibodies in mice and rhesus monkeys. Interestingly, DENV-2, as commented above, was the most prevalent serotype in 2017 in $\mathrm{Brazil}^{8}$. In this way, it would be expected that the herd immunity against ZIKV would increase, but not decrease the number of dengue cases in Brazil.

In Salvador, Brazil, Ribeiro et al. ${ }^{11}$ suggested that the decrease in dengue cases between 2015 and 2017 would be the result of the cross-herd immunity to ZIKV. Although Ribeiro et al. ${ }^{11}$ did not mention the circulating DENV serotypes in Salvador during the study, data from the Brazilian Ministry of Health demonstrated that the serotypes identified in Bahia in 2015 were DENV-1 (96.3\%) and DENV-4 $(3.7 \%)^{12}$ (data for 2016 and 2017 were not found).

In addition to the immunological explanations, vector-related factors should also be considered. About this, the increase of confirmed cases of chikungunya between 2016 and 2017 , from $151,318^{1}$ to $151,966^{2}$, weakens the hypothesis of the fall of DENV infection in 2017 as a consequence of vector control measures or environmental factors. Since 2015, DENV, ZIKV and Chikungunya virus (CHIKV) circulate in Brazil and Aedes aegypti coinfection with these arboviruses could favor the transmission of a specific virus, reflecting the change in the epidemiological pattern. However, when the vector was coinfected with two or three arboviruses (DENV-CHIKV and DENV-ZIKV) no advantages were observed for any of these viruses ${ }^{13-15}$. 
Therefore, despite the progress on cross-reactivity studies between flaviviruses and on the mosquito ecology, we believe that a more detailed analysis of the variables involved in the DENV-ZIKV interaction is required. We recognize that arboviruses outbreaks result from a complex interaction among several factors, such as environmental determinants, mosquito ecology, viral genetics, behavior and immunological background of the population ${ }^{5,6,16-19}$. However, it is important that the immunological studies are redesigned and carried out taking into account the multiple variables capable of influencing the cross-reaction between DENV and ZIKV: a) existence of different DENV serotypes, mainly DENV-4, which forms a group considerably distant from DENV- $1,-2$ and $-3^{20}$; b) animal model for in vivo studies; c) naïve populations or with history of previous flaviviruses infections; d) coinfection or immunity to other flaviviruses (e.g. Yellow fever virus and West Nile virus); e) existence of antibodies against conserved or flavivirus-specific regions of the envelope protein; f) genetic diversity of individuals' immune responses; g) intrinsic factors related to the viruses, such as possible mutations, mainly in the gene sequence coding for the envelope. Finally, we argue that only by narrowing the gap between laboratory assays and natural infections it will be possible to make substantiated interpretations on the epidemiology of the areas with flaviviruses co-circulation.

\section{CONFLICT OF INTERESTS}

The authors have no conflict of interest to disclose.

\author{
Thaísa Regina Rocha Lopes ${ }^{1}$ \\ Caroline Simões Silva ${ }^{2}$ \\ André Filipe Pastor ${ }^{3}$ \\ José Valter Joaquim Silva Júnior ${ }^{2}$
}

\section{REFERENCES}

1. Brasil. Ministério da Saúde. Secretaria de Vigilância em Saúde. Monitoramento dos casos de dengue, febre de chikungunya e febre pelo vírus Zika até a Semana Epidemiológica 52, 2016. Bol Epidemiol. 2017;48:1-11. [cited 2018 Jul 14]. Available from: http://portalarquivos2.saude.gov.br/images/pdf/2017/ abril/06/2017-002-Monitoramento-dos-casos-de-dengue-febre-de-chikungunya-e-febre-pelo-v--rus-Zika-ate-a-SemanaEpidemiologica-52--2016.pdf

2. Brasil. Ministério da Saúde. Secretaria de Vigilância em Saúde. Monitoramento dos casos de dengue, febre de chikungunya e febre pelo vírus Zika até a Semana Epidemiológica 52, 2017. Bol Epidemiol. 2018;49:1-13. [cited 2018 Jul 14]. Available from: http://portalarquivos2.saude.gov.br/images/pdf/2018/ janeiro/23/Boletim-2018-001-Dengue.pdf

3. Zanluca C, Melo VC, Mosimann AL, Santos GI, Santos CN, Luz K. First report of autochthonous transmission of Zika virus in Brazil. Mem Inst Oswaldo Cruz. 2015;110:569-72.

4. Faria NR, Azevedo RD, Kraemer MU, Souza R, Cunha MS, Hill $\mathrm{SC}$, et al. Zika virus in the Americas: early epidemiological and genetic findings. Science. 2016;352:345-9.

5. Silva Júnior JV, Lopes TR, Oliveira-Filho EF, Oliveira RA, Gil LH. Perspectives on the Zika outbreak: herd immunity, antibodydependent enhancement and vaccine. Rev Inst Med Trop Sao Paulo. 2017;59:e21.

6. Netto EM, Moreira-Soto A, Pedroso C, Höser C, Funk S, Kucharski AJ, et al. High Zika virus seroprevalence in Salvador, Northeastern Brazil limits the potential for further outbreaks. MBio. 2017;8:e01390-17

7. Brasil. Ministério da Saúde. Secretaria de Vigilância em Saúde. Monitoramento dos casos de dengue, febre de chikungunya e febre pelo vírus Zika até a Semana Epidemiológica 5 de 2018. Bol Epidemiol. 2018;49:1-14. [cited 2018 Jul 14]. Available from: http://portalarquivos2.saude.gov.br/images/pdf/2018/ fevereiro/20/2018-007.pdf

8. Brasil. Ministério da Saúde. Secretaria de Vigilância em Saúde. Monitoramento dos casos de dengue, febre de chikungunya e febre pelo vírus Zika até a Semana Epidemiológica 4, 2016. Bol Epidemiol. 2016;47:1-7. [cited 2018 Jul 14]. Available from: http://portalarquivos2.saude.gov.br/images/pdf/2016/ fevereiro/29/2016-005---Dengue-SE4-publica----o.pdf

9. Stettler K, Beltramello M, Espinosa DA, Graham V, Cassotta A, Bianchi S, et al. Specificity, cross-reactivity, and function of antibodies elicited by Zika virus infection. Science. 2016;353:823-6.

10. George J, Valiant WG, Mattapallil MJ, Walker M, Huang YS, Vanlandingham DL, et al. Prior exposure to Zika virus significantly enhances peak dengue-2 viremia in rhesus macaques. Sci Rep. 2017;7:10498.

11. Ribeiro GS, Kikuti M, Tauro LB, Nascimento LC, Cardoso CW, Campos GS, et al. Does immunity after Zika virus infection cross-protect against dengue? Lancet Glob Health. 2018;6:e140-1.

12. Brasil. Ministério da Saúde. Secretaria de Vigilância em Saúde. Monitoramento dos casos de dengue, febre de chikungunya e febre pelo vírus Zika até a Semana Epidemiológica 52, 2015. Bol Epidemiol. 2016;47:1-10. [cited 2018 Jul 14]. Available from: http://portalarquivos2.saude.gov.br/images/pdf/2016/ janeiro/15/svs2016-be003-dengue-se52.pdf

13. Le Coupanec A, Tchankouo-Nguetcheu S, Roux P, Khun H, Huerre M, Morales-Vargas R, et al. Co-infection of mosquitoes with chikungunya and dengue viruses reveals modulation of the replication of both viruses in midguts and salivary glands of Aedes aegypti mosquitoes. Int J Mol Sci. 2017;18:1708. 
14. Rückert C, Weger-Lucarelli J, Garcia-Luna SM, Young MC, Byas $\mathrm{AD}$, Murrieta RA, et al. Impact of simultaneous exposure to arboviruses on infection and transmission by Aedes aegypti mosquitoes. Nat Commun. 2017;8:15412

15. Göertz GP, Vogels CB, Geertsema C, Koenraadt CJ, Pijlman GP. Mosquito co-infection with Zika and chikungunya virus allows simultaneous transmission without affecting vector competence of Aedes aegypti. PLoS Negl Trop Dis. 2017;11:e0005654.

16. Mohan A, Kiran DH, Manohar IC, Kumar DP. Epidemiology, clinical manifestations, and diagnosis of Chikungunya fever: lessons learned from the re-emerging epidemic. Indian $\mathrm{J}$ Dermatol. 2010;55:54-63.
17. Viana DV, Ignotti E. The ocurrence of dengue and weather changes in Brazil: a systematic review. Rev Bras Epidemiol. 2013;16:240-56.

18. Fares RC, Souza KP, Añez G, Rios M. Epidemiological scenario of dengue in Brazil. Biomed Res Int. 2015;2015:321873.

19. Torres JR, Orduna TA, Piña-Pozas M, Vázquez-Vega D, Sarti E. Epidemiological characteristics of dengue disease in Latin America and in the Caribbean: a systematic review of the literature. J Trop Med. 2017;2017:8045435.

20. Venkatachalam R, Subramaniyan V. Homology and conservation of amino acids in E-protein sequences of dengue serotypes. Asian Pac J Trop Dis. 2014;4 Suppl 2):S573-7. 